\title{
Perception of Harrasment or Discrimination during Urology Residency in Colombia
}

\section{Percepción de acoso o discriminación durante la residencia de urología en Colombia}

\author{
Ana María Ortiz-Zableh ${ }^{1}$ Andres Felipe Quiñones Roa ${ }^{1}$ Bernardo Santamaria Fuerte ${ }^{1,2}$ \\ Veronica Tobar-Roa ${ }^{1,2}$ \\ ${ }^{1}$ Department of Urology, Universidad Autónoma de Bucaramanga \\ (UNAB), Floridablanca, Santander, Colombia \\ ${ }^{2}$ Centro Urológico Foscal, Clínica FOSCAL, Floridablanca, Santander, \\ Colombia \\ Address for correspondence Ana Maria Ortiz-Zableh, MD, \\ Departmento de Urología, Universidad Autónoma de Bucaramanga \\ (UNAB), Calle 155A \# 23-60, Floridablanca 681004, Santander, \\ Colombia (e-mail: Aortiz779@unab.edu.co).
}

Urol Colomb 2021;30(3):e184-e188.

\begin{abstract}
Keywords

- harassment

- internship and residency

- urology

- sexism

- Colombia

Purpose Workplace bullying (harassment, abuse, or discrimination), practiced persistently against an individual, can generate a hostile workplace environment, consequently leading to exhaustion, with poor psychological outcomes, and the onset of symptoms such as loss of confidence, fatigue, depressive thoughts, desertion, and suicidal thoughts. There are no publications regarding this issue in Colombia.

Our objective is to describe the residents' perception of gender and workplace discrimination and verbal/sexual harassment during their urological training.

Methods Observational, descriptive, cross-sectional study with anonymous surveys. We evaluated the demographic characteristics and the residents' perception of harassment, the type of harassment, how it affected their performance during residency, and from whom it was perceived.

Results We were able to obtain answers from 82/115 residents (71.3\%), most of them men (45 [56\%]). In total, 66\% (54) reported workplace harassment; and 35.4\% (29) felt gender discrimination, most of them women (17; 58.6\%). Verbal abuse was reported by $64.6 \%$ (53), and it affected the work of $92.5 \%$. The parception of workplace harassment was similar among both men and women (32 [69.5\%] men and 21 [61.1\%] women). A total of 7(19\%) women reported sexual abuse. Regarding the source of the abuse, 39 (65.8\%) was by professors, $26(45 \%)$, by other residents, and $17(35.4 \%)$, by patients. Conclusion The perception of harassment during urology residency in Colombia is real, and it affects the work of residents. This abuse is greater on the part of men, and is mainly perpetrated by professors. We consider our work the starting point to continue researching a topic of national and international importance.
\end{abstract}

received

January 10, 2021

accepted

July 2, 2021
DOI https://doi.org/

$10.1055 / \mathrm{s}-0041-1735787$.

ISSN 0120-789X.

e ISSN 2027-0119. (c) 2021. Sociedad Colombiana de Urología. All rights reserved. This is an open access article published by Thieme under the terms of the Creative Commons Attribution-NonDerivative-NonCommercial-License, permitting copying and reproduction so long as the original work is given appropriate credit. Contents may not be used for commercial purposes, or adapted, remixed, transformed or built upon. (https://creativecommons.org/ licenses/by-nc-nd/4.0/)

Thieme Revinter Publicações Ltda., Rua do Matoso 170, Rio de Janeiro, RJ, CEP 20270-135, Brazil 
Resumen

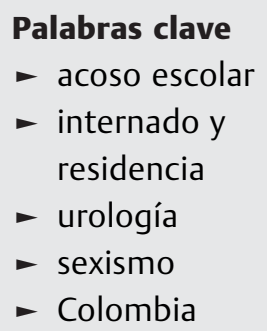

Objetivos El maltrato laboral (acoso, abuso o discriminación) ejercido de manera persistente contra un individuo genera un ambiente de trabajo hostil y lleva a agotamiento, con un impacto psicológico importante y la posibilidad de aparición de síntomas depresivos. En Colombia, no contamos con publicaciones al respecto. El objetivo de nuestro trabajo es conocer la percepción de los residentes de urología en cuanto a discriminación de género y acoso laboral, verbal y sexual durante su formación.

Metodos Estudio observacional, descriptivo, de corte transversal, por medio de encuestas anónimas. Evaluamos las características demográficas, la percepción de acoso, el tipo de acoso, si éste afectó el rendimiento laboral del residente, y por parte de quién lo percibió.

Resultados Obtuvimos respuestas de $82 / 115$ (71,3\%) residentes, en su mayoría hombres (45 [56\%]). En total, 66\% (54) reportaron haber experimentado acoso laboral; y 35,4\% (29) reportaron haber experimentado discriminación de género, siendo más frecuente en las mujeres (17; 58,6\%). El acoso verbal fue reportado por un 64,6\% (53), y afectó el trabajo de un 92,5\%. La percepción de acoso laboral fue similar entre hombres y mujeres (32 [69.5\%] hombres y 21 [61.1\%] mujeres). En total, 7 (19\%) mujeres reportaron acoso sexual. Con respecto a la fuente de acoso, 39 (65,8\%) fue por profesores, 26 (45\%), por otros residentes, y $17(35,4 \%)$, por pacientes.

Conclusión La percepción de acoso durante la residencia de urología en Colombia es real, y afecta el trabajo de los residentes. Este acoso es mayor por parte de los hombres, y es principalmente generado por profesores. Consideramos nuestro trabajo el punto de partida para continuar investigando un tema de importancia a nivel nacional y internacional.

\section{Introduction}

Workplace bullying, understood as harassment, intimidating behavior, abuse or discrimination that is practiced persistently against an individual, can generate a hostile work environment and consequently lead to exhaustion, with poor psychological outcomes among residents of medical or surgical specialties, and the onset of symptoms such as loss of confidence, fatigue, depressive thoughts and desertion, and even suicidal ideation. ${ }^{1,2}$ These behaviors are not identified in many cases, and are even tolerated and justified, as well as considered inherent to medical training.

Within the medical-surgical specialties, urology has reported the most prevalent rates of burnout syndrome, ${ }^{3}$ although it is striking that the issue of harassment itself has not been exhaustively studied. There is no literature on this topic specifically regarding Urology, and there is no published data on the perception of harassment, abuse, or discrimination during urology residency in Colombia.

Our objective is to describe the perception of gender and workplace discrimination and verbal/sexual harassment during urology residency, and how this is perceived to have an impact on health, job performance, and the learning process.

\section{Methods}

We performed an observational, descriptive, cross-sectional study, through an anonymous survey, that was designed by the authors and applied with permission of the Colombian Society of Urology (SCU), through an electronic platform of the SCU to all urology residents who agreed to participate.

All residents were invited to participate, and they could either accept or reject the invitation. The researchers respected the fundamental ethical principles through verbal consent, which was reflected in the autonomous and voluntary completion of the collection instrument.

The questions evaluated the demographics of the residents, and their perception of harassment, the type of harassment, how it affected their performance during residency, and from whom it was perceived (-Appendix A).

A non-probabilistic sample of the participants who agreed to answer the survey was calculated.

A descriptive analysis was performed using the Stata (StataCorp., LLC, Colege Station, TX, United States) software, version 15. The descriptive component was developed according to the nature of the variables; the qualitative ones, using absolute and relative frequencies, and the quantitative variables, with measures of central tendency, position, and dispersion according to the frequency distribution. 
The difference by gender regarding the perception of bullying by other residents, teachers, nurses and patients was estimated with a binomial test to contrast two proportions. The significance level of the study was $5 \%$.

\section{Results}

All urology residents at Colombian urology faculties were invited to participate in our study in February 2020. At that time, there was a total of 115 residents: 62 (54\%) men and 53 (46\%) women (data provided by the SCU in February 2020). We were able to obtain answers from 82/115 residents (71.3\%). - Table 1 summarizes the demographics of the surveyed residents.

Regarding workplace harassment, 66\% (54) of the residents reported that they have felt some behavior of aggression/harassment at work during their residency. Considering non-exclusive responses, $89 \%$ (48) reported that this type of harassment impacted their hospital work. Regarding gender discrimination, 35.4\% (29) reported it; 16 (55.2\%) of them referred that these behaviors affected their work as residents. In regards to verbal harassment, 64.6\% (53) referred to have been the object of destructive criticism and insults, and 49 (92.5\%) of them referred that their work as a resident was affected because of the criticism.

There was no difference between genders in terms of workplace harassment (69.5\% of men and $61.1 \%$ of women), unlike what was found in terms of gender discrimination: it was referred in a significantly higher percentage by women (7 [26\%] men and 13 [47.2\%] of women). Sexual harassment has been perceived by 7 (19\%) women; all of those who answered affirmatively to this question said that this type of harrasment affected their work and their development as residents.

Finally, a characterization was made to define from whom had the residents perceived harassment: among the options were patients, teachers, residents, nursing staff, or none. In total, $6(10 \%)$ residents answered that none of the above; of the remaining $90 \%, 45 \%$ felt harassed by other residents $(37, p=0.0112)$. We divided this answer by gender, finding

Table 1 Demographics of the surveyed residents

\begin{tabular}{|c|c|c|}
\hline $\mathrm{N}$ & 82 & \\
\hline \multirow[t]{3}{*}{ Gender: n (\%) } & Male & $46(56 \%)$ \\
\hline & Female & $36(43.9 \%)$ \\
\hline & Other & 0 \\
\hline \multirow[t]{4}{*}{ Residency year: n (\%) } & First & $17(20.7 \%)$ \\
\hline & Second & $27(32.9 \%)$ \\
\hline & Third & $20(24.3 \%)$ \\
\hline & Fourth & $17(20.7 \%)$ \\
\hline \multirow[t]{3}{*}{ Marital status: $\mathrm{n}(\%)$} & Single & $71(86.5 \%)$ \\
\hline & Married & $5(6.09 \%)$ \\
\hline & Consensual union & $6(7.3 \%)$ \\
\hline
\end{tabular}

that 26 men and 11 women felt it; $65.8 \%$ felt harassed by teachers (54: 31 men and 23 women; $p=0.740$ ), 29\%, by nursing staff (24: 13 men and 11 women; $p=0.821$ ), and 35.4 ,\% by patients (29: 15 men and 14 women; $p=0.555$ ).

\section{Discussion}

The results of our survey show that $66 \%$ of residents have perceived workplace harassment, and $35.4 \%$ of them, gender discrimination (7 (26\%) men and 13 (47.2\%) women). Harassment can lead to a decrease in the satisfaction perceived by the residents regarding their training process, and consequently lead to secondary mistreatment of the patients. ${ }^{1}$

This problem has been studied in the United States, Asia, Canada and Europe, ${ }^{1,2,4}$ although there is limited literature published regarding this topic worldwide. In a systematic review and metanalysis of 59 articles conducted in 2011, Fnais et al. ${ }^{3}$ found that $59.4 \%$ of training doctors had experienced some sort of abuse or discrimination, (95\% confidence interval [95\%CI]: 52.0-66.7\%), and verbal abuse was the most frequently reported. The abuse was mostly reported by specialists, followed by patients and relatives of patients. ${ }^{3}$

Fnais et al. ${ }^{5}$ applied a survey to 213 residents in Saudi Arabia in 2013 , finding that $83.6 \%$ of them had perceived some sort of abuse, mostly verbal abuse (61.5\%), followed by gender discrimination (58.3\%). Sexual abuse was reported by $19.3 \%$ of residents, most of them women $(p=0.061) .{ }^{5}$ Our survey shows that residents have felt abuse mostly by professors (both men and women), followed by other residents $(39(65.8 \%)$ by professors and $26(45 \%)$ by other residents).

Workplace harassment is a problem that has been related to surgical specialties. In a recent study ${ }^{4}$ published in the New England Journal of Medicine, a survey was applied to residents of surgical specialties in the United States: gender discrimination was reported by $31.9 \%$ of the participants (65\% of women); $30.2 \%$ referred verbal abuse or emotional abuse (33\% of women), being most of the time by an attending surgeon (52.4\%), and by other residents (20\%). Physical abuse was only reported by $2.2 \%$. Sexual abuse was reported by $10.3 \%$ of those surveyed, being mostly by patients or relatives of patients (31.2\%), surgeons (30.9\%), residents (15.4\%), and nurses $(11.7 \%){ }^{4}$

Fitzgerald et al. ${ }^{6}$ applied the HITS (Hurt, Insulted, Threatened with harm or Screamed at) screening tool in a multicenter study with 76 surgery residents conducted in 2019 , finding that sexual abuse was the most commonly reported (28\%), followed by gender discrimination (15.7\%), and race discrimination (7.9\%). Participants were also asked about the emotional impact abuse brought with it: $36.8 \%$ felt anger, $31.6 \%$, frustration, $30.2 \%$, shame, and $25 \%$ reported anxiety. ${ }^{6}$ In the present study, 48 out of 54 residents (88\%) answered that this abuse had affected their work as residents.

It is interesting that, even though there has been a increasing number of women studying urology in our country in the last years, ${ }^{7}$ and the number of women in academic and executive positions has been growing, there still exists a 
perception of gender discrimination and sexual abuse. ${ }^{8}$ As there are no previous studies regarding this topic, we do not know if this harassment was greater when there were fewer women in our specialty.

A metanalysis ${ }^{9}$ conducted in 2014 found a perception of sexual abuse with a mean prevalence of $33 \%$ among students and female residents, compared with $4 \%$ of men. ${ }^{9}$ Ortiz Zableh et al. ${ }^{7}$ applied surveys to female urologists and female urology residents in Colombia, and found that 18 out of 53 urologists (34\%) and 15 out of 36 residents (41.7\%) referred workplace harassment. Our survey showed that 7 residents (19\%) referred sexual abuse during residency, all of them women.

The present study has some disadvantages, such as the fact that the survey was applied via an electronic platform, without full representation of the residents nationwide.

The present is the first national study that evaluates the perception of harassment by urology residents, and it shows how the quality of their work during residency is being affected. More national and international studies, including residents from all specialties, are required to get more results and evaluate the possible reasons behind this harassment (work overload, gender discrimination, discrimination by patients, among others).

\section{Conclusions}

The perception of harassment during urology residency in Colombia is real, and it affects the work of residents. This abuse is greater on the part of men, and is mainly perpetrated by professors and other residents. We consider the present work the starting point to continue researching a topic of national and international importance.
Funding

The authors have no source of funding to declare.

Conflict of Interests

The authors have no conflict of interests to declare.

\section{References}

1 Nagata-Kobayashi S, Maeno T, Yoshizu M, Shimbo T. Universal problems during residency: abuse and harassment. Med Educ 2009;43(07):628-636

2 Rodríguez-Socarrás M, Vasquez JL, Uvin P, Skjold-Kingo P, Gómez Rivas J. "Síndrome de agotamiento": Estrés, Burnout y depresión en Urología. Arch Esp Urol 2018;71(01):46-54

3 Fnais N, Soobiah C, Chen MH, et al. Harassment and discrimination in medical training: a systematic review and meta-analysis. Acad Med 2014;89(05):817-827

4 Hu Y-Y, Ellis RJ, Hewitt DB, et al. Discrimination, Abuse, Harassment, and Burnout in Surgical Residency Training. N Engl J Med 2019;381(18):1741-1752

5 Fnais N, al-Nasser M, Zamakhshary M, et al. Prevalence of harassment and discrimination among residents in three training hospitals in Saudi Arabia. Ann Saudi Med 2013;33(02): 134-139

6 Fitzgerald CA, Smith RN, Luo-Owen X, et al. Screening for harassment, abuse, and discrimination among surgery residents: An EAST multicenter trial. Am Surg 2019;85(05):456-461

7 Ortiz Zableh AM, Santamaría Fuerte B, Tobar Roa V. Situación actual de la mujer en Urología en Colombia. Arch Esp Urol 2021;74 (02):187-196

8 Bates CK, Jagsi R, Gordon LK, et al. It Is Time for Zero Tolerance for Sexual Harassment in Academic Medicine. Acad Med 2018;93 (02):163-165

9 Jagsi R, Griffith KA, Jones R, Perumalswami CR, Ubel P, Stewart A. Sexual harassment and discrimination experiences of academic medical faculty. JAMA 2016;315(19):2120-2121 


\section{Appendix A Questions applied}

1. Sex
a. Man
b. Woman
c. Other

2. Residency year
a. 1
b. 2
c. 3
d. 4

3. Marital status
a. Single
b. Married
c. Consensual union
d. Widowed

4. Have you felt workplace harassment during residency?
a. Yes
b. No

5. If your answer to question 4 was yes, did the perception of harassment affect your work as a resident?
a. Yes
b. No

6. Have you felt gender discrimination during residency?
a. Yes
b. No

7. If your answer to question 6 was yes, did the perception of harassment affect your work as a resident? a. Yes

b. No

8. Have you felt verbal abuse during residency?
a. Yes
b. No

9. If your answer to question 8 was yes, did the perception of harassment affect your work as a resident?

a. Yes

b. No

10. Have you felt sexual abuse during residency?
a. Yes
b. No

11. If your answer to question 10 was yes, did the perception of harassment affect your work as a resident?
a. Yes
b. No

12. By whom have you felt this abuse? (mark any of the options)
a. Residents
b. Professors
c. Nurses
d. Patients
e. Others (please specify) 